\title{
The Chick Chorioallantoic Membrane: A Model of Molecular, Structural, and Functional Adaptation to Transepithelial Ion Transport and Barrier Function during Embryonic Development
}

\author{
Maria Gabriella Gabrielli and Daniela Accili \\ Department of Comparative Morphology and Biochemistry, University of Camerino, Via Gentile III da Varano, \\ 62032 Camerino, Italy \\ Correspondence should be addressed to Maria Gabriella Gabrielli, gabriella.gabrielli@unicam.it
}

Received 21 July 2009; Revised 16 November 2009; Accepted 6 January 2010

Academic Editor: Amanda McCann

Copyright ( $) 2010$ M. G. Gabrielli and D. Accili. This is an open access article distributed under the Creative Commons Attribution License, which permits unrestricted use, distribution, and reproduction in any medium, provided the original work is properly cited.

The chick chorioallantoic membrane is a very simple extraembryonic membrane which serves multiple functions during embryo development; it is the site of exchange of respiratory gases, calcium transport from the eggshell, acid-base homeostasis in the embryo, and ion and $\mathrm{H}_{2} \mathrm{O}$ reabsorption from the allantoic fluid. All these functions are accomplished by its epithelia, the chorionic and the allantoic epithelium, by differentiation of a wide range of structural and molecular peculiarities which make them highly specialized, ion transporting epithelia. Studying the different aspects of such a developmental strategy emphasizes the functional potential of the epithelium and offers an excellent model system to gain insights into questions partly still unresolved.

\section{Introduction}

The amniotic egg represents a fundamental reproductive strategy in colonization of terrestrial habitat. The novelty of the amniotic egg is the presence of three extraembryonic membranes, amnios, chorion, and allantois, which surround the embryo, mediate between it and the environment, and provide an aqueous medium to complete development and ontogenetic program inside the eggshell. The allantoic membrane often reaches and fuses with the chorion to create the chorioallantoic membrane (CAM). This extremely vascular envelope is crucial for chick development in that it is responsible for transport of calcium from the eggshell into the embryo, besides functioning in gas exchange, acid-base balance in the embryo, water, and electrolyte reabsorption from the allantoic cavity where urinary waste products are discharged.

Identification of such a functional complexity by a relatively simple structure goes back to classic work of several investigators [1-8] which have elucidated and described the CAM unique features as the basis for understanding its multiple implications in the morphogenetic events. Over the decades, the research interest on the chick CAM has been shared by investigators working in embryology, morphology, biochemistry, and physiology, in an attempt to relate the different functions of the CAM to the structural features of its epithelia as well as to identify molecular components and mechanisms by which these functions are accomplished [921].

The most recent investigations have been addressed to clarifying mainly the CAM respiratory properties [22-24] and the multifunctional meaning of its structural patterns $[25,26]$. In addition, studies in our laboratories have been performed and are still in progress, mainly aimed to elucidate the expression and significance of the CAM glycosylation patterns, as well as to identify and characterize membrane molecular components implicated in the ion transport processes which occur in the chorionic epithelium [27-31].

In this review article, by collecting data from the pertinent literature and especially from our own results, we aim to put together a comprehensive picture of the chick CAM, which may emphasize how this extraembryonic membrane, in spite of its relatively simple cytoarchitecture, can solve a series of complex functional demands by means 

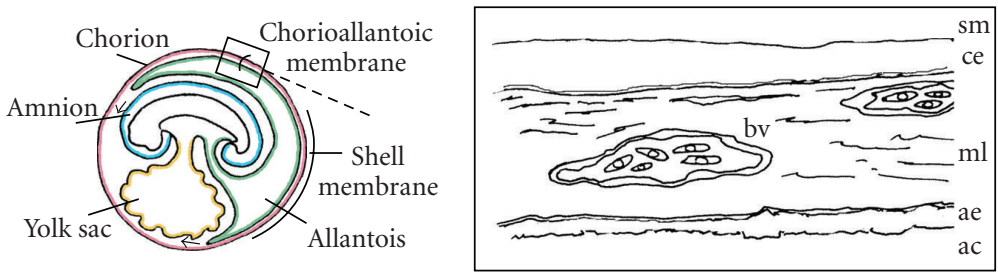

(a)

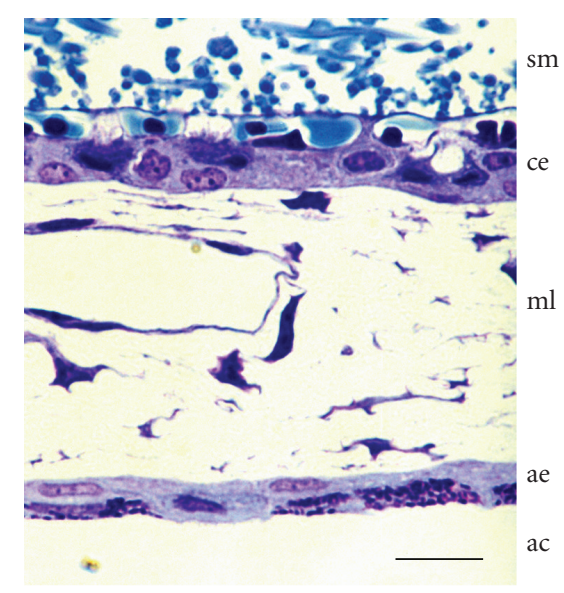

(b)

FIgURE 1: The three-tissue layers of the chick mature CAM are indicated in the schematic representation in (a) and clearly recognizable at day 16 of incubation, after Toluidine blue staining (b): the chorionic epithelium (ce) adheres to the shell membrane (sm); the intermediate mesodermal layer ( $\mathrm{ml}$ ) contains blood vessels; the allantoic epithelium (ae) lines the allantoic cavity (ac). (a) Modified from Gabrielli et al. [30]. (b) Original magnification: 40x; scale bar: $8 \mu \mathrm{m}$; M. G. Gabrielli, unpublished.

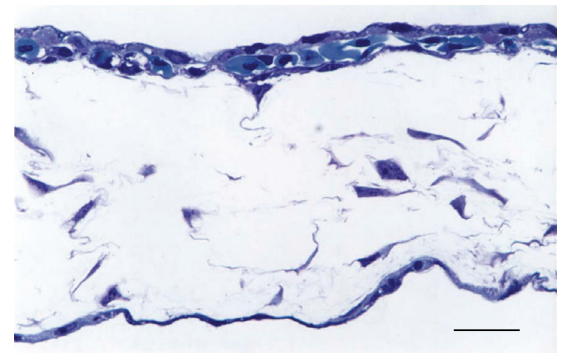

(a)

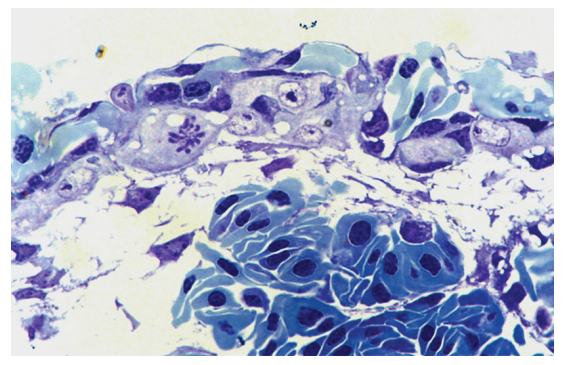

(b)

Figure 2: Two successive aspects of differentiating capillary plexus, at day 8 ((a) original magnification: $40 x$; scale bar: $10 \mu \mathrm{m})$ and day 11 ((b) original magnification: 100x; scale bar: $5 \mu \mathrm{m}$ ) of incubation. The chorionic epithelium in (b) shows early cellular proliferation. Toluidine blue staining. M. G. Gabrielli, unpublished.

of high specializations which involve either differentiation of morphological peculiarities and expression of specific biochemical markers in its epithelia.

\section{Structural Features of the Chorionic and Allantoic Epithelium in Developing and Mature CAM: From a Simple Layer of Flattened Cells to a Mosaic of Distinct and Highly Specialized Cell Types}

The CAM forms between days 5 and 6 of incubation by partial fusion of chorion and allantois $[2,32]$ and progressively develops adhering to acellular inner shell membrane, found just inside the egg shell, until it surrounds the embryo and other egg contents by days 11 and 12 [8]. Structurally, the CAM is a very simple cellular membrane consisting of three layers derived from distinct embryonic tissues (Figure 1): the ectodermal chorionic epithelium that is in direct contact with the inner shell membrane, the intermediate mesoderm enriched in blood vessels and stromal components, and the endodermal allantoic epithelium that lines the allantoic cavity $[3,4,9]$. By day 10 of incubation, the CAM also comprises the fully developed capillary plexus, an extensive capillary network which gradually comes to lie in a plane on the outer surface of the chorion (Figure 2).

Histological complexity of both the chorionic and the allantoic epithelium greatly increases during incubation. At day 7, both components of the membrane are single layers of flattened cells. Subsequent differentiation produces characteristic epithelial cell layers, distinctly different in histological appearance and comprising heterogeneous cell populations. The onset and progression of such a differentiation has been discussed in relation to the timing of physiological changes in the embryo. Thus, it has been suggested that the undifferentiated chorionic epithelium may serve a protective function by preventing inward diffusion of ions prior to the time at which calcium and bicarbonate are required by the developing chick embryo [17].

The main changes occur in the CAM epithelia by days 10 to 11. Striking cellular proliferation becomes now a prominent feature in the chorionic layer (Figure 2(b)) 


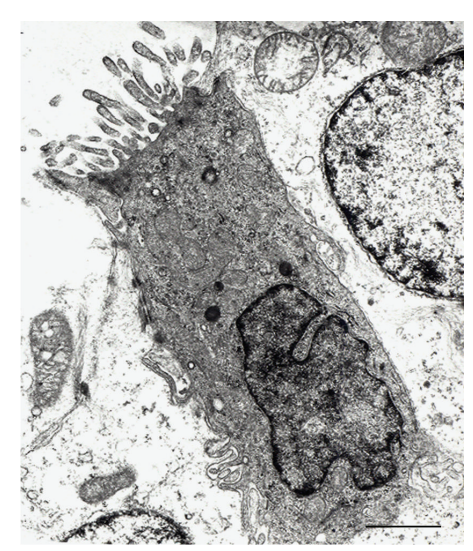

(a)

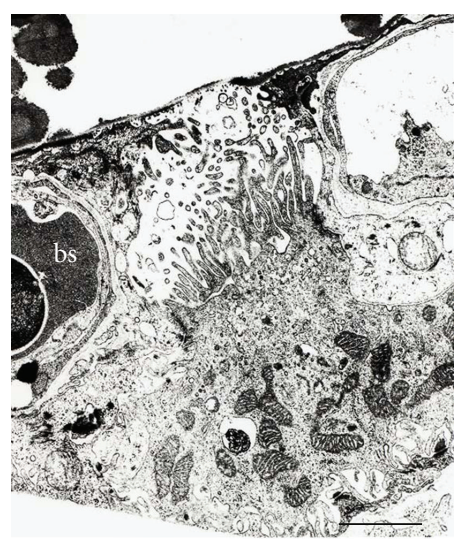

(b)

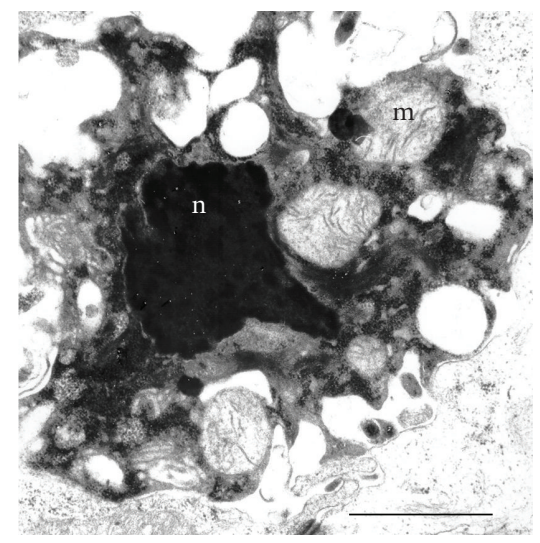

(c)

Figure 3: VC cells at early stage of differentiation ((a) original magnification: 19,600x; scale bar: $2 \mu \mathrm{m})$ are present in the CAM at day 13 of incubation, interspersed among the fully differentiated ones (b, original magnification: 11,000x; scale bar: $3 \mu \mathrm{m}$ ). Also elements with the appearance of apoptotic cells are frequently observed (c) original magnification: 33,000x; scale bar: $3 \mu \mathrm{m}$ ). blood sinus (bs); m, mitochondria; n, nucleus. M. G. Gabrielli, unpublished.

while certain areas of the allantoic epithelium appear to be in transition, the flattened cells assuming a more cuboidal form. As reported by Dunn and Fitzharris [17], most superficial cells of the chorionic epithelium appear relatively electron lucent and contain euchromatic nuclei, prominent mitochondria, perinuclear Golgi membranes, and microfilaments. Electron-lucent cells are attached to adjacent cells of the same layer by junctional complexes. At random sites, electrondense cells with long finger-like projections along the cell surface and nuclei containing peripheral heterochromatin were observed (Figure 3(a)). All these findings, as also confirmed by our observations (Figures 3, 4(a), and 4(b)), document the first steps toward differentiation of two distinct cell types, the villus cavity (VC) cells and the capillary covering (CC) cells, which characterize the mature chorionic epithelium. By day 12, the VC cells become terminally differentiated and exhibit their distinctive features (Figure 3(b)): an electron-dense cytoplasm, numerous mitochondria and the apical cell membrane folded in thin microvilli which protrude into a large depression beneath the inner shell membrane [4]. Concomitantly, cells presenting intense vacuolation, electron-dense cytoplasm, swollen mitochondria, and irregular piknotic nuclei can be observed (Figure 3(c)). Their occurrence has been related to possible apoptotic processes as those accompanying the differentiation program of several organs [17]. Also differentiating CC cells can be recognized. They acquire their mature, distinctive features at about day 14. At this time, the CC cells make up most of the CAM surface by developing long cytoplasmic extensions which overlie the chorionic capillary plexus (Figures $4(\mathrm{a})$ and $4(\mathrm{~b})$ ).

Parallel developmental changes in the allantoic epithelium result in differentiation, at about days 11-12 of incubation, of three different cell types, basal cells (BC), granulerich cells (GRC), and mitochondria-rich cells (MRC), which differ in size, position through the epithelium, and content in cytoplasmic granules $[4,7]$. Electron microscopic analysis further details the subcellular peculiarities of such a cell diversity [26, 31] (Figure 4(c)).

\section{The Role of the Intermediate Mesodermal Layer}

Both the CAM epithelia lie, at the opposite sides, on the intermediate mesenchyme which originates from the the mesodermal layer of the chorion and the mesodermal layer of the allantois at the moment of their fusion to form the CAM.

The mesodermal layer is the site of the early development of the extraembryonic vascular system which serves the CAM epithelia and forms the chorionic capillary plexus. The timing and features of the CAM vasculogenesis have been widely described [32-34]. Data have been also reported on the cytochemical aspects that characterize the steps of this process, mainly concerning the composition of the extracellular matrix and the modulation of glycoconjugates produced by endothelial cells and smooth muscle cells, in relation to significant cellular events of the vascular morphogenesis [34].

The blood vessels appear at day 4 as a network of primitive, irregularly spaced tubules with large luminal diameters, scattered in the mesodermal layer. From days 5 to 10 , CAM vessels progressively differentiate into capillaries, arterioles, and venules. Vessels destinated to be capillaries migrate to a position beneath the ectodermal layer of the CAM and form a dense plexus of small vessels (Figure 2(a)). On about day 7 , the capillaries begin to migrate outward between the ectodermal cells until they are located at the surface of the CAM at day 12 (Figure 2(b)).

The arterial and venous blood vessels which supply the capillary plexus remain situated in the deeper mesodermal tissue (Figures 1(b) and 2(b)). By this vascular arrangement, which probably makes the blood circulation rather slow, and 


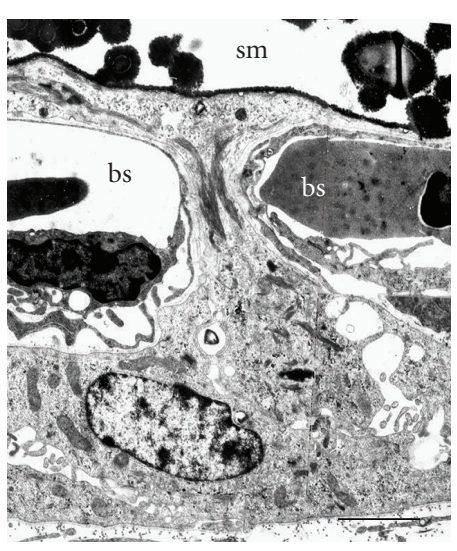

(a)

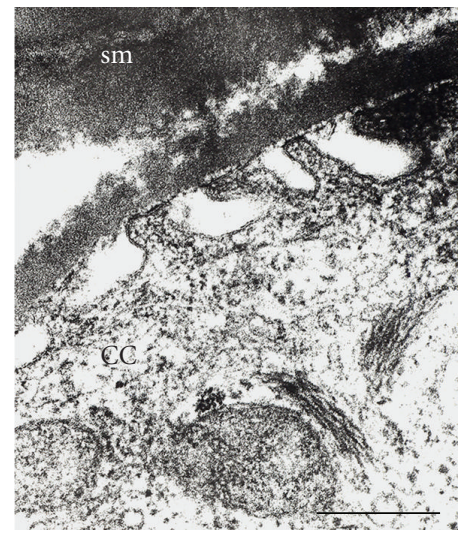

(b)

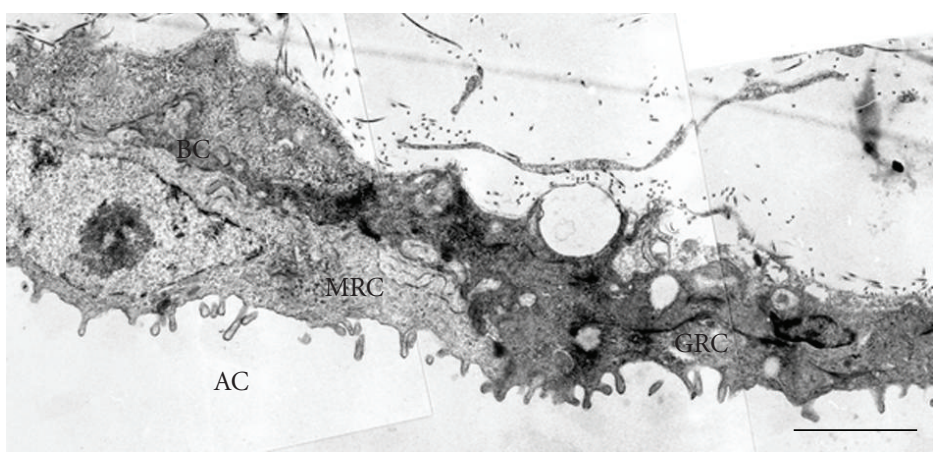

(c)

FIGURE 4: (a) A CC cell shows its typical cytoplasmic lateral projections which separate the shell membrane (sm) from the capillaries of the blood sinus (bs). Original magnification: 11,200x; scale bar: $2 \mu \mathrm{m}$. (b) Apical pits are formed by CC cell membrane adjacent to the inner shell membrane (sm). Original magnification: 70,000x; scale bar: $0.5 \mu \mathrm{m}$. (c) Basal cells (BC), mitochondria-rich cells (MRC), and granule-rich cells (GRC) characterize the CAM allantoic epithelium which faces the allantoic cavity (AC). Original magnification: $21,700 x$; scale bar: $1 \mu \mathrm{m}$. M. G. Gabrielli, unpublished.

by its position immediately adjacent to the porous shell, gaseous exchange with the environment is facilitated.

\section{Transepithelial Ion Transport in the CAM Meets Multiple Functional Demands of the Developing Embryo}

4.1. The Calcium Transport through the Chorionic Epithelium: An Open Question. During the embryonic development, calcium is reabsorbed from the eggshell and is transferred to the embryo for bone formation [1]. The chorionic epithelium, which is the first cellular barrier to the entry of calcium from the eggshell into the embryonic circulation, has been shown to comprise the calcium-transporting region of the CAM. Several in vivo and in vitro studies have clarified some aspects of the CAM calcium transport function $[6,12$, $13,19,35-40]$. The chorionic epithelial cells mobilize and transport eggshell calcium into the embryonic circulation in a development-specific manner, starting at days 10-12 and peaking around day 17 of incubation, concomitantly with the onset of calcium accumulation by the embryo. The CAM calcium transport has been shown to be a unidirectional, active process that is highly specific for $\mathrm{Ca}^{2+}$ and is differently regulated by vitamin $\mathrm{K}$ and $\mathrm{D}$ [41-46] and availability of eggshell calcium for transport $[18,47]$.

Likewise, the specific cellular mechanism of transepithelial calcium transport in the CAM have been widely investigated. The research interest has been focused on the close association between the specific morphological changes occurring in the chorionic epithelium and the expression of the calcium transport activity. By day 10 of development, the CC cells develop a tight adhesion to the inner shell membrane, such that the structural integrity and calcium transport activity of the CAM are lost if the inner shell membrane is mechanically removed $[6,35,36$, 48]. Concomitantly, their cytoplasmic extensions become extensive and narrow so that the capillaries approach the eggshell calcium reserve more closely [4]. By day 15, prior to the peak of transport activity $[6,38,49]$, the CC cells contain few membranous organelles, and lack endoplasmic reticulum and Golgi apparatus [4]. In conjunction with these specific morphological features, the chorionic epithelium expresses biochemical activities associated with calcium transport. These activities include a vitamin $\mathrm{K}$ dependent $\mathrm{Ca}^{2+}$-binding protein (CaBP or transcalcin) $[15$, 37, 50-52], an enhanced $\mathrm{Ca}^{2+}$-activated, $\mathrm{Mg}^{2+}$-dependent ATPase activity [10], and carbonic anhydrase (CA) activity 
$[11,16,53]$. All these proteins are localized in the chorionic epithelium; specifically, the CaBP is a peripheral membrane protein associated with the cell surface of the epithelium that faces the shell membrane [15]; the $\mathrm{Ca}^{2+}$-ATPase is an integral membrane component, which appears to exist in close topographic association to the $\mathrm{CaBP}[10]$; carbonic anhydrase, firstly recognized only as a cytosolic component $[11,39]$, seems to be present also as a membrane-associated form $[27,54]$. The last suggestion awaits further support from studies in progress in our laboratories. Each of these biochemical activities has been functionally linked to CAM calcium transport in vitro and in vivo [39]. Moreover, a specificity of their distribution with respect to the cell types of the chorionic epithelium was established $[10,11,28,55]$.

In order to elucidating the specific mechanisms involved in the transepithelial translocation of calcium by the CAM, a pinocytosis model has been proposed by Terepka and his group [6] and later modified [12, 15, 39, 40, 52]. This model involves the endocytic uptake of solubilized eggshell calcium at the apical surface of the chorionic CC cells, followed by internalization and vesicle-mediated delivery to the basolateral surface. By analyzing cell-free microsomes of the CAM in in vitro calcium-uptake assay systems, Tuan and collaborators [39] have discussed the inability of the anti-CaBP antibodies to inhibit microsomal calcium uptake. They have suggested that the subcellular vesicles are probably inside-out structures, with the CaBP located inside and therefore inaccessible to the exogenously applied antibodies. In this manner, the CaBP therefore serves as an internal calcium sink for the subcellular vesicles in vitro or as a calcium sequestrator on the shell-facing ectodermal cell surface in vivo. They have postulated that subcellularly fractionated, calcium-uptake-competent microsomal vesicles would be formed from plasma membranes and would contain at least the $\mathrm{CaBP}$ and the $\mathrm{Ca}^{2+}$-ATPase, the former located in the internal space of the vesicles whereas the latter is an integral membrane protein oriented so that ATP hydrolysis is coupled to inward translocation of calcium. In line with the transcytosis model, the CaBP, localized at the apical surface of the CC cells [15], may be postulated as serving the role of a cell surface "calcium-specific receptor" which upon calcium binding triggers specific, adsorptive endocytosis leading to the formation of pinocytic vesicles that contain the $\mathrm{CaBP}$ and the membranous $\mathrm{Ca}^{2+}$-ATPase, in a manner similar to that in the cell-free microsomal vesicles studied in vitro. Finally, by a still unclear mechanism, the calcium load would be delivered to the serosal side of the perivascular processes of the ectodermal cells, whereas component(s) of the transport apparatus may be recycled to the proper region of the plasma membrane facing the calcium source [39]. The analysis of the subcellular distribution of ${ }^{45} \mathrm{Ca}^{2+}$ accumulated from the extracellular medium into cultured chick chorionic cells $[19$, 56] have contributed additional experimental data in favour of the vesicle-mediated model of transcellular calcium transport. It has been observed that both the kinetic profiles and the levels of whole cell calcium accumulation and cytosolic $\mathrm{Ca}^{2+}$ flux differ dramatically thus suggesting that the pathway of calcium uptake from the extracellular medium involves sequestration into an internal compartment separate from the cytosol. Such a hypothetical specialized pathway of calcium entry in the chorionic epithelial cells may be also related to the unique kinetic profiles that the calcium influx has shown in the CC cells as compared with other calcium transporting epithelia, such as primary chick duodenal cells and LLC-MK2 kidney cells [19]. On the other hand, it has been outlined that when the CC cells become terminally differentiated in vivo, concomitantly to the calcium transport increase, they lose biosynthetic machinery and maintain few membranous organelles available for calcium sequestration $[4,5]$. Instead, their cytoplasmic extensions, surrounding the capillary plexus, show a significant number of vesicles as well as numerous endocytotic-like pits formed by invagination of the cell membrane in direct contact with the inner shell membrane (Figure 4(b)) [4, 15, 17, 31]. This hypothetical mechanism, and its suggested morphological correlates, may be strengthened by similarities with the model proposed for osteoclasts in reabsorbing bone calcium, as recently reviewed by Coxon and Taylor [57]. In discussing vesicular trafficking in osteoclasts, they report that calcium derived from the bone mineral is likely removed by a transcytotic pathway, since calcium has been localized within transcytotic vesicles directly [58]. Moreover, also compounds that bind calcium, such as tetracycline and bisphosphonate drugs, localize to transcytotic vesicles upon uptake from mineralized surfaces by osteoclasts $[59,60]$. A transcellular route is suggested to be likewise important for the removal of calcium from the resorption lacuna [61], most likely following uptake into the osteoclast via the TRPV5 calcium channel [62]. Recently, a new perspective on the facilitated diffusion and vesicular transport models, which accounts for the emerging concepts on transcellular calcium transport, has been discussed also for transepithelial $\mathrm{Ca}^{2+}$ transfer in intestine, kidney, mammary glands, placenta, and gills of fish [63].

Neither has to be ruled out the possible coexistence in the CAM of different pathways for the calcium transfer through the chorionic epithelium. In particular, the large occurrence of apical cellular junctions, previously identified as tight junctions [56], might be functionally related to a paracellular calcium transport, as recently reported in intestinal and renal epithelia where distinct claudins have proved to be most likely involved in paracellular $\mathrm{Ca}^{2+}$ transport [64].

Unfortunately, in last years no additional data have been provided to clarifying the calcium-transport pathways in the CAM. Most of the mechanisms proposed actually remains largely speculative and need to be further investigated also in the light of latest knowledge on analogous functions in adult model systems.

4.2. The Model of VC Cells. Two other aspects pertinent to the mechanism of calcium transport by the CAM have to be considered. First, how is the calcite mineral $\left(\mathrm{CaCO}_{3}\right)$ of the eggshell solubilized before calcium transport? Second, what processes regulate the metabolic fate of the $\mathrm{HCO}_{3}{ }^{-}$ liberated from the shell after its solubilization and during active calcium transport by the CAM?

The answers to these questions are linked to the development in the chick CAM of further specializations 


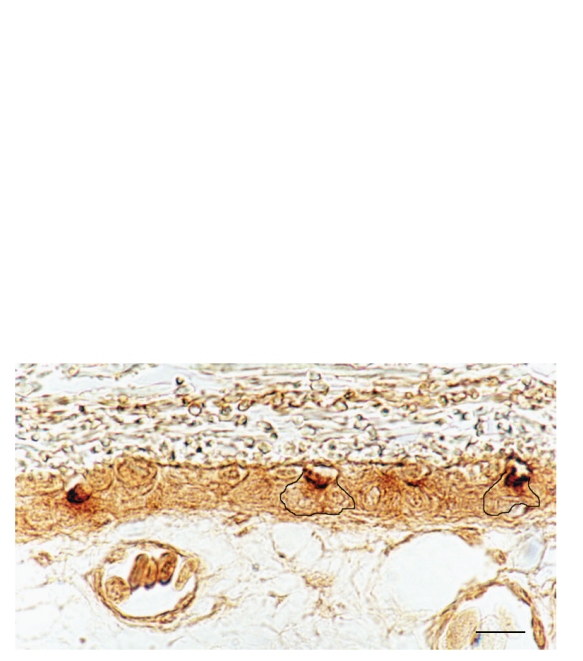

(a)

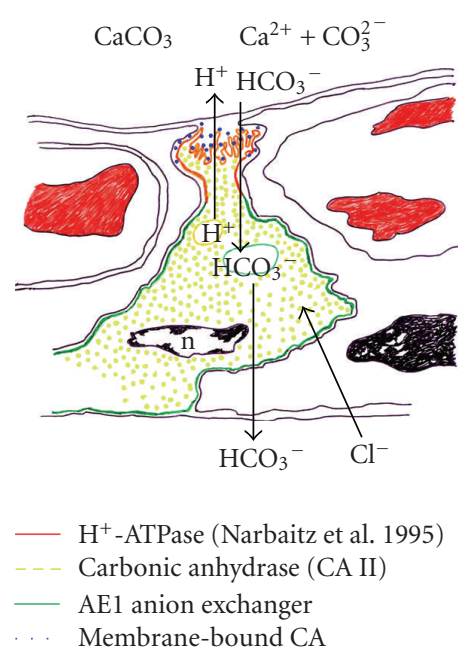

(b)

FIgURE 5: (a) Anti-CAIV staining at the apical cell membrane of the VC cells in the chick CAM at 17 day of incubation. Original magnification: 100x; scale bar: $5 \mu \mathrm{m}$. (b) A schematic representation of the functional model proposed for the VC cells in bicarbonate absorption for acid-base balance in the embryo. M. G. Gabrielli, unpublished.

which find their specific expression in the other distinct cell type present in the chorionic epithelium, the VC cells. Their morphological features, clearly defined by recent ultrastructural investigations also by our group [25,31], fully fit with specialized functional roles, as suggested on the basis of contents in specific molecular markers. Indeed, it is now well established that VC cells specifically express carbonic anhydrase (CA) [28], an almost quite ubiquitous enzyme which catalyzes the hydration of metabolic carbon dioxide and dehydration of bicarbonate during acid-base regulation. Since its first identification in the chick CAM $[16,65]$, increasing evidence from different experimental approaches has indicated an involvement of CA activity in the CAMmediated processes occurring during chick development [11, $38,39,52,53]$. More precisely, based also on the profile of its developmentally-regulated activity as well as on its localization in the chorionic epithelial cells $[55,66]$, the expression of carbonic anhydrase, though firstly considered as directly involved in calcium transfer, has been then definitely related to the production of protons to be secreted apically for solubilization of the eggshell mineral calcite. In this context, our finding that CA expression in the chorionic epithelium is specifically restricted to the VC cells and never found in CC cells [28] well correlates with the previous demonstration that vacuolar $\mathrm{H}^{+}$-ATPase accumulates in the apical membranes and subapical vesicles in VC cells [21]. The $\mathrm{H}^{+} \mathrm{V}$-ATPase is known to contribute in the cell membranes to regulation of intracellular $\mathrm{pH}$, secretion of acid, and generation of transmembrane electrical gradients that serve as a driving force for transport across the membrane of these cells [67]. Taken together, the findings above have suggested that VC cells are a specialized chorionic cell type which, via a vacuolar-type $\mathrm{H}^{+}$-ATPase present at the apical pole, pumps protons generated by cytoplasmic carbonic anhydrase towards the egghshell. Proton secretion results in regional acidification, thereby causing solubilization of the mineral calcite [68]. Hence, $\mathrm{Ca}^{2+}$ ions become available to be reabsorbed into the embryo.

The specialization panel of the VC cells has then been enriched by data from our subsequent investigations: a developmentally-regulated and cell type-specific expression of AE1 anion exchanger, the electroneutral transporter which mediates the exchange of $\mathrm{Cl}^{-}$for $\mathrm{HCO}_{3}{ }^{-}$across the cell plasma membrane in a wide variety of cell types [69], was demonstrated for the first time in the CAM epithelia [30]. In the chorionic epithelium, AE1 was restricted to the basolateral membranes of the VC cells which, at electron microscopic analysis, clearly showed that AE1 specifically accumulates in extensive projections extending from the lateral membrane of VC cells towards the adjacent CC cells (Figure 5(a)). The basolateral membranes of the adjacent CC cells as well as the apical membranes of both CC cells and VC cells were always unlabelled [30].

The coexpression of carbonic anhydrase and AE1 in chorionic VC cells suggests that AE1 may act in the maintenance of $\mathrm{pH}$ equilibrium in these cells which are engaged apically in $\mathrm{H}^{+}$secretion via the vacuolar-type $\mathrm{H}^{+}$-ATPase. In such a functional model, VC cells show similarities with acidsecretory type A-intercalated cells of the kidney collecting ducts where basolateral AE1 anion exchangers and apical Vtype $\mathrm{H}^{+}$-ATPase function co-ordinately in the presence of intracellular carbonic anhydrase [70-74].

In last years, the functional link between CAs and bicarbonate transport proteins in facilitation of transepithelial bicarbonate transport was suggested to imply, in some cases, apparently direct interactions [75-78]. In particular, the binding of intracellular CAII to the cytosolic $\mathrm{COOH}-$ terminal tails of the AE1 exchangers has been previously proposed [76]. Localization of CAs immediately adjacent to bicarbonate transporters in bicarbonate transport 
TABLE 1: A schematic view of transepithelial ion transport functions through the chorionic epithelium.

\begin{tabular}{|c|c|c|c|}
\hline Functions & Sites and mechanisms & $\begin{array}{l}\text { Molecular and structural } \\
\text { components }\end{array}$ & References \\
\hline \multirow{6}{*}{$\begin{array}{l}\text { Calcium reabsorption from the } \\
\text { eggshell }\end{array}$} & $\begin{array}{l}\text { Capillary covering cells: } \\
\text { pinocytosis model }\end{array}$ & & $\begin{array}{l}{[6,12,13,15,19,35-} \\
38,40,56]\end{array}$ \\
\hline & & $\begin{array}{l}\text { Tight adhesion of cell } \\
\text { membranes to shell } \\
\text { membrane, apical vesiscles, } \\
\text { and endocytotic-like pits }\end{array}$ & $\begin{array}{l}{[4,6,15,17,31,35,36,48,} \\
56]\end{array}$ \\
\hline & & $\mathrm{Ca}^{2+}$-binding protein & $\begin{array}{l}{[4-6,15,17,18,37,39,50-} \\
52]\end{array}$ \\
\hline & & $\mathrm{Ca}^{2+}$ ATPase & {$[10,15,39]$} \\
\hline & & Carbonic anhydrase & {$[11,39]$} \\
\hline & Paracellular transport & Apical tight junctions & {$[56]$} \\
\hline \multirow{2}{*}{$\begin{array}{l}\text { Proton secretion for solubilization of } \\
\text { the eggshell mineral calcite }\end{array}$} & \multirow{2}{*}{ Villus cavity cells } & Carbonic anhydrase & {$[16,28,39,52,53,55,68]$} \\
\hline & & Vacuolar $\mathrm{H}^{+}$-ATPase & {$[21]$} \\
\hline \multirow{3}{*}{$\begin{array}{l}\text { Bicarbonate transport for acid-base } \\
\text { homeostasis in the embryo }\end{array}$} & Villus cavity cells & & \\
\hline & $\begin{array}{l}\text { (i) bicarbonate } \\
\text { reabsorption from the } \\
\text { eggshell to the embryo }\end{array}$ & AE1 anion exchanger & {$[30]$} \\
\hline & $\begin{array}{l}\text { (ii) } \mathrm{HCO}_{3}{ }^{-} \text {influx from the } \\
\text { eggshell into the VC cells }\end{array}$ & $\begin{array}{l}\text { Membrane-associated } \\
\text { carbonic anhydrase }\end{array}$ & {$[27,54]$} \\
\hline
\end{tabular}

metabolons may maximize the transmembrane bicarbonate concentration gradient in the immediate locale of the transporter polypeptide, thus increasing bicarbonate transport rate [79]. In the CAM, our double immunofluorescence findings, showing erythrocyte CAII closely restricted to the cell membranes where AE1 localizes, are in line with the metabolon hypothesis. The coexpression of AE1 and CAII in the chorionic VC cells suggests that a metabolon may exist also in these cells to maximize bicarbonate transport [30].

Based on the functional requirements of the developing embryo, it may be further speculated on the VC cell specialized role. Besides contributing to local acidification through apical proton pumps, these cells, via their basolateral AE1 anion exchangers, could contribute to the maintenance of acid-base balance during development by reabsorbing $\mathrm{HCO}_{3}{ }^{-}$ions into the embryo. Indeed, as development proceeds, acid production by the embryo increases and exceeds the limiting rate of $\mathrm{CO}_{2}$ diffusion through the shell and its membranes. This requires a corresponding increase in the concentration of plasma bicarbonate to prevent metabolic acidosis. Although the excretory system can also contribute, the eggshell is regarded as the main source of this extra "nonrespiratory" bicarbonate $[80,81]$. Thus, besides the intracellular $\mathrm{HCO}_{3}{ }^{-}$derived from the activity of the cytosolic carbonic anhydrase, the main source of this $\mathrm{HCO}_{3}{ }^{-}$supply for the embryo would be the $\mathrm{HCO}_{3}{ }^{-}$ ions released together with calcium ions from solubilization of the eggshell. Reabsorption of these ions through the chorionic VC cells, via the basolateral AE1, might explain the gradual increase in plasma bicarbonate concentration during development [82].
In such a context, mechanisms mediating $\mathrm{HCO}_{3}{ }^{-}$influx from the eggshell into the VC cells should be also hypothesized. Possible candidates might be apical $\mathrm{Na}^{+} / \mathrm{HCO}_{3}{ }^{-}$ cotransporters, as already established in several tissues [8386]. Although at present no conclusive data are available, an alternative mechanism might occur. Indeed, using antibodies against the membrane-associated human CAIV isoenzyme, we detected a specific immunostaining at the apical membranes of the VC cells (Figure 5(a)). The finding indicates that a membrane-associated form of carbonic anhydrase, which shares antigenic properties with human CAIV, may exist at the VC cell apical pole [27]. At this site, analogously with mammalian CAIV isoenzyme, it might promote the conversion of $\mathrm{HCO}_{3}{ }^{-}$ions, originated from the eggshell dissolution, to $\mathrm{CO}_{2}$ which can diffuse promptly across the apical membrane into the cells. In the VC cell cytoplasm, $\mathrm{CO}_{2}$ would be converted to $\mathrm{HCO}_{3}{ }^{-}$ions by the cytosolic CAII, then leaving the basolateral pole via the AE1 anion exchangers (Figure 5(b)). Promising results seem likely to derive from current studies [54] aimed to validate the specificity of the immunohistochemical finding as well as to further characterize the membrane-associated CA isoform in the chicken tissues which, to date, are known to express only cytosolic forms of carbonic anhydrase [87].

In reviewing morphofunctional features by which transepithelial ion transport occurs in the chorionic epithelium, a last contribution comes from elucidation of the glycosylation patterns expressed in the CAM during embryonic development [29]. Indeed, it is known that studying the specific cell carbohydrate expression may provide data on functional specializations in several biological systems. 
TABLE 2: A schematic view of the functional roles of the allantoic epithelium.

\begin{tabular}{lllr}
\hline Functions & Sites and mechanisms & Molecular components & References \\
\hline $\begin{array}{l}\text { Ion and } \mathrm{H}_{2} \mathrm{O} \text { reabsorption } \\
\text { from the allantoic fluid }\end{array}$ & Allantoic epithelial cells & & \\
\hline $\begin{array}{l}\text { Proton secretion towards } \\
\text { the allantoic fluid and } \\
\text { bicarbonate reabsorption }\end{array}$ & Mitochondria-rich cells & Vacuolar H ${ }^{+}$-ATPase & Carbonic anhydrase \\
\hline $\begin{array}{l}\text { Defence against luminal } \\
\text { toxic contents }\end{array}$ & Granule-rich cells-secretion & AE1 anion exchanger & [21] \\
\hline
\end{tabular}

A preferential location of lectin binding sites at the supranuclear cytoplasm and apical cell membrane of the VC cells was observed, consistent with the morphofunctional polarity of this cell type. In particular, a high occurrence of sialoglycoconjugates was mostly evidenced suggesting that sialic acids might act in preventing adhesion of the numerous long cellular processes of the VC cell apical membranes. This would maintain the efficiency of ion transport occurring at these sites via the vacuolar $\mathrm{H}^{+}$-ATPase [21] and $\mathrm{Ca}^{2+}{ }_{-}$ ATPase activity [39]. Also the PNA binding sites, located at the apical cell surfaces, well agree with electrolyte transport mechanisms. Indeed, a codistribution of proton pumps and PNA binding sugars has elsewhere been reported [88-90].

\section{The Contribution of the Allantoic Epithelium}

The allantoic epithelium, although is a thin cell layer, constitutes an important barrier against the allantoic fluid. It acts as a selectively permeable barrier, permitting the absorption of electrolytes and water while maintaining an effective defence against intraluminal toxic contents. To this function probably contribute the numerous cell-cell junctions present between the cells facing the lumen. The results from the in situ characterization of glycocomponents expressed in the allantoic epithelium also may be viewed in favour of a barrier function, required to provide the embryo a highly selected environment [29]. Indeed, a large occurrence of $\alpha$ Fuc in the allantoic cells was inferred by LTA lectin staining from the early stages of the tissue differentiation up to its regression. On the basis of either the hydrophobic nature of fucose and the preferential affinity of LTA to $\alpha$-Fuc residues located in the outer region of the oligosaccharide chains [91], the specific expression of fucose in the CAM epithelium lining the allantoic cavity conforms to a defence function by preventing diffusion of toxic substances from the allantoic fluid to the embryo. Moreover, a high expression of different sialoderivatives has been evidenced, mainly located in the granule-rich cells, in line with the previous demonstration of acidic glycocomponents at these sites (our unpublished observations). The significance of their occurrence on the epithelial surface lining the allantoic cavity is, at present, unknown. Based on its high hydrophilic properties, sialic acid might be responsible, as elsewhere reported [92], for maintaining a hydration coat on the allantoic luminal surface, aimed at either promoting $\mathrm{H}_{2} \mathrm{O}$ reabsorption by the allantoic MR cells [7] or providing a protection against the toxic contents of the allantoic fluid. The high amount of granule-rich cells within the epithelium, as compared to the other cell types, as well as the localization of lectin labelling mostly in their granules support the possibility that the granule-rich cells are the specialized sites of the defence function in the allantoic epithelium.

A likewise specialized, although distinct role may be attributed to the mitochondria-rich cells. They exhibit subcellular characteristics, such as a large number of studs in their apical plasma membranes, which are typical of proton secreting cells. This similarity has been further supported by localization of vacuolar $\mathrm{H}^{+}$-ATPase in these cells, leading to the hypothesis that they may be involved in $\mathrm{H}^{+}$secretion towards the allantoic fluid [21]. Mitochondria-rich cells express also the cytosolic isoform of carbonic anhydrase, CAII $[21,28]$, as well as the AE1 anion transporter, restricted to the cell basolateral membranes [30]. Altogether these results let us to suggest that MR cells may have a part in maintaining acid-base homeostasis during development. A partial reabsorption of bicarbonate to the embryo may thus be achieved by the allantoic epithelium, too. The pattern of expression of the above biochemical markers provides the complete machinery necessary for proton secretion coupled to bicarbonate reabsorption. This machinery likely contributes to the progressive acidification of the allantoic fluid that has been reported to occur during development [8]. Lastly, our finding that no AE1 immunoreactivity is detectable at the apical membrane of mitochondria-rich cells [30], cannot confirm the suggestion that, similarly to the type B-intercalated cells of the kidney collecting ducts and reptilian bladders, the allantois would contain a second type of mitochondria-rich cells which secrete $\mathrm{H}^{+}$through the base and $\mathrm{HCO}_{3}{ }^{-}$through the apex [21].

In past years, a few studies have outlined the role of the allantoic epithelium in reabsorpting water from the allantoic fluid as a crucial function for the embryo development. During incubation, allantoic fluid volume initially increases, reaches a maximum on days 12-13 and then declines rapidly until hatching to serve the needs from the embryo. Based on available data, the osmotic gradient favourable for water reabsorption would be maintained by the selective removal of sodium and chloride from the allantoic fluid while the concentration of calcium, potassium, and phosphorus, in addition to uric acid, urea, and other nitrogen excretory products, are increased [7, 93]. Again, in order to evaluate further the mechanisms by which the allantoic epithelial cells participate in ion transport functions, new data are required. 


\section{Concluding Remarks}

A main consideration prompts out in conclusion. It does not surprise that the CAM presents a very simple structure when considering it is an embryonic membrane deriving from a likewise simple developmental pathway, moreover confined in the limited space of a cleidoic egg. Instead, it is surprising and fascinating to realize how high and complex is the level of functional specialization the CAM can reach to serve multiple requirements during embryo development. Such a hard engagement is mainly entrusted to the capability of its epithelia and it is skillfully solved by differentiation of a mosaic of strategies, including cell heterogeneity within the epithelium as well as high variety of cellular and molecular specificities, mainly aimed at optimizing distinct ion transport processes (Tables 1 and 2 ). The importance of such a solution is evident when considering that on its efficiency depends the success of ontogenesis.

Nowadays, many aspects of the CAM involvement in transepithelial ion transport, however, remain still to be fully defined. Unfortunately, in last years the research progress on the chick CAM has been scanty. Instead, the most studies concerning the CAM have been, and are currently focused on its use in vivo as a model to examine angiogenesis and antiangiogenesis in response to normal tissues and cells, to tumour bioptic specimens and cells, or to soluble factors [94-99]. The chick CAM has proven to be also a useful tool in drug transport assays for development of pharmaceuticals [100] as well as in assays using CAMengrafted human skin for identification of cosmetic allergens [101].

Nevertheless, the progress of studies on the cellular and molecular mechanisms of CAM physiology appears still of interest and may have implications not only for developmental biology. In fact, several aspects of the CAM specializations, and their relevant functional meanings, seem to anticipate features and mechanisms by which analogous functions, such as proton secretion, calcium transport, bicarbonate reabsorption, are carried out in different tissues of adult animals. This strengths the value of the CAM as an excellent model system to further explore, by means of more recent methodological approaches as well as in specific experimental conditions, questions partly still unresolved. At the light of the available data, even unique aspects in the CAM transport mechanisms may be expected, possibly related to the unique characteristics of this embryonic membrane, such as the severity of its functional implication for the developing embryo. Elucidation of the transport pathways occurring in the CAM, by eventually pointing out novel and/or conserved mechanisms, might thus be of interest also for their evolutionary significance. At this regards, a recent stimulating study, by suggesting that steroidogenic activity of extraembryonic membranes is not a novel characteristic of placental amniotes [102], might raise new interests and perspectives for evaluating further the multiple functional roles of the chorioallantoic membrane.

\section{References}

[1] P. M. Johnston and C. L. Comar, "Distribution and contribution of calcium from the albumen, yolk and shell to the developing chick embryo," The American Journal of Physiology, vol. 183, no. 3, pp. 365-370, 1955.

[2] A. L. Romanoff, The Avian Embryo: Structural and Functional Development, Macmillan, New York, NY, USA, 1960.

[3] T. S. Leeson and C. R. Leeson, "The chorio-allantois of the chick. Light and electron microscopic observations at various times of incubation," Journal of Anatomy, vol. 97, pp. 585595, 1963.

[4] J. R. Coleman and A. R. Terepka, "Fine structural changes associated with the onset of calcium, sodium and water transport by the chick chorioallantoic membrane," The Journal of Membrane Biology, vol. 7, no. 1, pp. 111-127, 1972.

[5] J. R. Coleman and A. R. Terepka, "Electron probe analysis of the calcium distribution in cells of the embryonic chick chorioallantoic membrane. II. Demonstration of intracellular location during active transcellular transport," The Journal of Histochemistry and Cytochemistry, vol. 20, no. 6, pp. 414-424, 1972.

[6] A. Terepka, M. Stewart, and N. Merkel, "Transport function of the chick chorioallantoic membrane. II. Active calcium transport, in vitro," Experimental Cell Research, vol. 58, no. 1, pp. 107-117, 1969.

[7] M. E. Stewart and A. R. Terepka, "Transport functions of the chick chorio-allantoic membrane. I. Normal histology and evidence for active electrolyte transport from the allantoic fluid, in vivo," Experimental Cell Research, vol. 58, no. 1, pp. 93-106, 1969.

[8] B. M. Freeman and M. A. Vince, Development of the Avian Embryo. A Behavioural and Physiological Study, Chapman \& Hall, London, UK, 1974.

[9] R. Narbaitz, "Cytological and cytochemical study of the chick chorionic epithelium," Experimental Biology, vol. 31, no. 4, pp. 259-267, 1972.

[10] R. S. Tuan and K. A. Knowles, "Calcium-activated ATPase of the chick embryonic chorioallantoic membrane: identification, developmental expression, and topographic relationship with calcium-binding protein," Journal of Biological Chemistry, vol. 259, no. 5, pp. 2754-2763, 1984.

[11] R. S. Tuan, "Carbonic anhydrase and calcium transport function of the chick embryonic chorioallantoic membrane," Annals of the New York Academy of Sciences, vol. 429, pp. 459472, 1984.

[12] A. Terepka, J. Coleman, H. Armbrecht, and T. Gunther, "Transcellular transport of calcium," in Calcium in Biological System, C. Duncan, Ed., Symposia of the Society for Experimental Biology, no. 30, pp. 117-140, Cambridge University Press, Cambridge, UK, 1976.

[13] J. R. Coleman, S. M. Dewitt, P. Batt, and A. R. Terepka, "Electron probe analysis of calcium distribution during active transport in chick chorioallantoic membrane," Experimental Cell Research, vol. 63, no. 1, pp. 216-220, 1970.

[14] A. S. M. Saleuddin, C. P. M. Kyriakides, A. Peacock, and K. Simkiss, "Physiological and ultrastructural aspects of ion movements across the chorioallantois," Comparative Biochemistry and Physiology, vol. 54, no. 1, pp. 7-12, 1976.

[15] R. S. Tuan, W. A. Scott, and Z. A. Cohn, "Calciumbinding protein of the chick chorioallantoic membrane. I. Immunohistochemical localization," Journal of Cell Biology, vol. 77, no. 3, pp. 743-751, 1978. 
[16] R. S. Tuan and J. Zrike, "Functional involvement of carbonic anhydrase in calcium transport of the chick chorioallantoic membrane," Biochemical Journal, vol. 176, no. 1, pp. 67-74, 1978.

[17] B. E. Dunn and T. P. Fitzharris, "Differentiation of the chorionic epithelium of chick embryos maintained in shellless culture," Developmental Biology, vol. 71, no. 2, pp. 216227, 1979.

[18] B. E. Dunn, J. S. Graves, and T. P. Fitzharris, "Active calcium transport in the chick chorioallantoic membrane requires interaction with the shell membranes and/or shell calcium," Developmental Biology, vol. 88, no. 2, pp. 259-268, 1981.

[19] R. E. Akins and R. S. Tuan, "Transepithelial calcium transport in the chick chorioallantoic membrane. II. Compartmentalization of calcium during uptake," Journal of Cell Science, vol. 105, no. 2, pp. 381-388, 1993.

[20] M. J. Packard, "Mobilization of shell calcium by the chick chorioallantoic membrane in vitro," The Journal of Experimental Biology, vol. 190, pp. 141-153, 1994.

[21] R. Narbaitz, B. Bastani, N. J. Galvin, V. K. Kapal, and D. Z. Levine, "Ultrastructural and immunocytochemical evidence for the presence of polarised plasma membrane $\mathrm{H}^{+}$-ATPase in two specialised cell types in the chick embryo chorioallantoic membrane," Journal of Anatomy, vol. 186, no. 2, pp. 245-252, 1995.

[22] K. Wagner-Amos and R. S. Seymour, "Effect of regional changes to shell conductance on oxygen consumption and growth of chicken embryos," Respiration Physiology, vol. 129, no. 3, pp. 385-395, 2002.

[23] V. F. Maksimov and I. M. Korostyshevskaia, "Developmental peculiarities of gas transporting system in chick embryo under respiratory surface restriction," Rossiüskii fiziologicheskiu zhurnal imeni I.M. Sechenova, vol. 93, no. 12, pp. 14131422, 2007.

[24] I. M. Korostyshevskaia and V. F. Maksimov, "How chicken embryo survives after half of shell is sealed?" Ontogenez, vol. 40, no. 2, pp. 136-147, 2009.

[25] V. F. Maksimov, I. M. Korostyshevskaya, and S. A. Kurganov, "Functional morphology of chorioallantoic vascular network in chicken," Bulletin of Experimental Biology and Medicine, vol. 142, no. 3, pp. 367-371, 2006.

[26] I. M. Korystyshevskaia, V. F. Maksimov, and V. I. Baranov, "Multifunctional morphology of the chick chorioallantoic membrane," Rossiǔskii fiziologicheskiu zhurnal imeni I.M. Sechenova, vol. 92, no. 7, pp. 889-901, 2006.

[27] M. G. Gabrielli, "Carbonic anhydrases in chick extraembryonic structures: a role for CA in bicarbonate reabsorption through the chorioallantoic membrane," Journal of Enzyme Inhibition and Medicinal Chemistry, vol. 19, no. 3, pp. 283-286, 2004.

[28] M. G. Gabrielli, G. Materazzi, J. V. Cox, and G. Menghi, "Specialised cell types in the chorioallantoic membrane express carbonic anhydrase during chick embryogenesis," Journal of Anatomy, vol. 198, no. 2, pp. 229-238, 2001.

[29] M. G. Gabrielli, G. Materazzi, A. M. Bondi, and G. Menghi, "Developmental expression of glycocomponents in the chick chorioallantoic membrane," Anatomy and Embryology, vol. 207, no. 1, pp. 63-71, 2003.

[30] M. G. Gabrielli, J. V. Cox, G. Materazzi, and G. Menghi, "Cell type-specific and developmentally regulated expression of the AE1 anion exchanger in the chicken chorioallantoic membrane," Histochemistry and Cell Biology, vol. 121, no. 3, pp. 189-199, 2004.
[31] M. G. Gabrielli, D. Accili, and G. Menghi, "Ultrastructural patterns of the epithelial cell heterogeneity in chick chorioallantoic membrane," Italian Journal of Anatomy and Embryology, vol. 111, p. 111, 2006.

[32] G. Melkonian, N. Munoz, J. Chung, C. Tong, R. Marr, and P. Talbot, "Capillary plexus development in the day five to day six chick chorioallantoic membrane is inhibited by cytochalasin D and suramin," Journal of Experimental Zoology, vol. 292, no. 3, pp. 241-254, 2002.

[33] R. Narbaitz, "Structure of the intra-chorionic blood sinus in the chick embryo," Journal of Anatomy, vol. 124, no. 2, pp. 347-354, 1977.

[34] D. H. Ausprunk, "Distribution of hyaluronic acid and sulfated glycosaminoglycans during blood-vessel development in the chick chorioallantoic membrane," American Journal of Anatomy, vol. 177, no. 3, pp. 313-331, 1986.

[35] J. C. Garrison and A. R. Terepka, "Calcium-stimulated respiration and active calcium transport in the isolated chick chorioallantoic membrane," The Journal of Membrane Biology, vol. 7, no. 1, pp. 128-145, 1972.

[36] J. C. Garrison and A. R. Terepka, "The interrelationships between sodium ion, calcium transport and oxygen utilization in the isolated chick chorioallantoic membrane," The Journal of Membrane Biology, vol. 7, no. 1, pp. 146-163, 1972.

[37] R. S. Tuan and W. A. Scott, "Calcium binding protein of chorioallantoic membrane: identification and developmental expression," Proceedings of the National Academy of Sciences of the United States of America, vol. 74, no. 5, pp. 1946-1949, 1977.

[38] R. S. Tuan, "Calcium transport and related functions in the chorioallantoic membrane of cultured shell-less chick embryos," Developmental Biology, vol. 74, no. 1, pp. 196-204, 1980.

[39] R. S. Tuan, M. J. Carson, J. A. Jozefiak, K. A. Knowles, and B. A. Shotwell, "Calcium-transport function of the chick embryonic chorioallantoic membrane. II. Functional involvement of calcium-binding protein, $\mathrm{Ca}^{2+}$-ATPase and carbonic anhydrase," Journal of Cell Science, vol. 82, pp. 8597, 1986.

[40] R. S. Tuan, T. Ono, R. E. Akins, and M. Koide, "Experimental studies on cultured, shell-less fowl embryos: calcium transport, skeletal development, and cardio-vascular functions," in Egg Incubation: Its Effects on Embryonic Development in Birds and Reptiles, D. C. Deeming and M. W. J. Ferguson, Eds., pp. 419-433, Cambridge University Press, Cambridge, UK, 1991.

[41] R. S. Tuan, "Vitamin K-dependent $\gamma$-glutamyl carboxylase activity in the chick embryonic chorioallantoic membrane," Journal of Biological Chemistry, vol. 254, no. 4, pp. 1356$1364,1979$.

[42] R. Tuan and T. Ono, "Regulation of extraembryonic calcium mobilization by the developing chick embryo," Journal of Embryology and Experimental Morphology, vol. 97, pp. 63-74, 1986.

[43] M. A. Elaroussi and H. F. DeLuca, "Calcium uptake by chorioallantoic membrane: effects of vitamins D and K," American Journal of Physiology, vol. 267, no. 6, part 1, pp. E837-E841, 1994.

[44] M. A. Elaroussi, A. Uhland-Smith, W. Hellwig, and H. F. DeLuca, "The role of vitamin D in chorioallantoic membrane calcium transport," Biochimica et Biophysica Acta, vol. 1192, no. 1, pp. 1-6, 1994. 
[45] M. J. Packard, N. B. Clark, and J. P. Erickson, "The effect of calcium-regulating hormones on transport of calcium across the chorioallantoic membrane of the chicken embryo," Comparative Biochemistry and Physiology, vol. 119, no. 2, pp. 547-552, 1998.

[46] R. Narbaitz, C. P. W. Tsang, and A. A. Grunder, "Effects of vitamin D deficiency in the chicken embryo," Calcified Tissue International, vol. 40, no. 2, pp. 109-113, 1987.

[47] R. S. Tuan, "Supplemented eggshell restores calcium transport in chorioallantoic membrane of cultured shell-less chick embryos," Journal of Embryology and Experimental Morphology, vol. 74, pp. 119-131, 1983.

[48] C. M. Moriarty and A. R. Terepka, "Calcium transport by the isolated chick chorio-allantoic membrane," Archives of Biochemistry and Biophysics, vol. 135, pp. 160-165, 1969.

[49] R. J. Crooks and K. Simkiss, "Calcium transport by the chick chorioallantois in vivo," Quarterly Journal of Experimental Physiology, vol. 60, no. 1, pp. 55-63, 1975.

[50] R. S. Tuan, W. A. Scott, and Z. A. Cohn, "Calcium-binding protein of the chick chorioallantoic membrane. II. Vitamin K-dependent expression," Journal of Cell Biology, vol. 77, no. 3, pp. 752-761, 1978.

[51] R. S. Tuan, W. A. Scott, and Z. A. Cohn, "Purification and characterization of calcium-binding protein from chick chorioallantoic membrane," Journal of Biological Chemistry, vol. 253, no. 4, pp. 1011-1016, 1978.

[52] R. S. Tuan, "Mechanism and regulation of calcium transport by the chick embryonic chorioallantoic membrane," Journal of Experimental Zoology, vol. 244, supplement 1, pp. 1-13, 1987.

[53] R. Narbaitz, S. Kacew, and L. Sitwell, "Carbonic anhydrase activity in the chick embryo chorioallantois: a regional distribution and vitamin D regulation," Journal of Embryology and Experimental Morphology, vol. 65, pp. 127-137, 1981.

[54] M. G. Gabrielli, D. Tomassoni, S. Vincenzetti, and D. Accili, "Carbonic anhydrases in avian tissues: membrane-associated CA is a glycosylphosphatidylinositol-anchored protein and resists in situ to SDS treatment," in Proceedings of the 8th International Conference on Carbonic Anhydrases, Florence, Italy, 2009.

[55] R. E. Anderson, C. V. Gay, and H. Schraer, "Ultrastructural localization of carbonic anhydrase in the chorioallantoic membrane by immunocytochemistry," The Journal of Histochemistry and Cytochemistry, vol. 29, no. 10, pp. 1121-1127, 1981.

[56] R. E. Akins and R. S. Tuan, "Transepithelial calcium transport in the chick chorioallantoic membrane. I. Isolation and characterization of chorionic ectoderm cells," Journal of Cell Science, vol. 105, no. 2, pp. 369-379, 1993.

[57] F. P. Coxon and A. Taylor, "Vesicular trafficking in osteoclasts," Seminars in Cell \& Developmental Biology, vol. 19, no. 5, pp. 424-433, 2008.

[58] M. Yamaki, H. Nakamura, N. Takahashi, N. Udagawa, and H. Ozawa, "Transcytosis of calcium from bone by osteoclastlike cells evidenced by direct visualization of calcium in cells," Archives of Biochemistry and Biophysics, vol. 440, no. 1, pp. 10-17, 2005.

[59] J. Salo, P. Lehenkari, M. Mulari, K. Metsikkö, and H. K. Väänänen, "Removal of osteoclast bone resorption products by transcytosis," Science, vol. 276, no. 5310, pp. 270-273, 1997.
[60] F. P. Coxon, K. Thompson, A. J. Roelofs, F. H. Ebetino, and M. J. Rogers, "Visualizing mineral binding and uptake of bisphosphonate by osteoclasts and non-resorbing cells," Bone, vol. 42, no. 5, pp. 848-860, 2008.

[61] H. K. Datta and B. R. Horrocks, "Mechanisms of calcium disposal from osteoclastic resorption hemivacuole," Journal of Endocrinology, vol. 176, no. 1, pp. 1-5, 2003.

[62] B. C. J. van der Eerden, J. G. J. Hoenderop, T. J. de Vries, et al., "The epithelial $\mathrm{Ca}^{2+}$ channel TRPV5 is essential for proper osteoclastic bone resorption," Proceedings of the National Academy of Sciences of the United States of America, vol. 102, no. 48, pp. 17507-17512, 2005.

[63] R. C. Khanal and I. Nemere, "Regulation of intestinal calcium transport," Annual Review of Nutrition, vol. 28, pp. 179-196, 2008.

[64] H. Fujita, K. Sugimoto, S. Inatomi, et al., "Tight junction proteins claudin-2 and -12 are critical for vitamin Ddependent $\mathrm{Ca}^{2+}$ absorption between enterocytes," Molecular Biology of the Cell, vol. 19, no. 5, pp. 1912-1921, 2008.

[65] R. P. Heckey and A. Owczarzak, "The chorioallantoic membrane histochemistry and electron microscopy of carbonic anhydrase," Journal of Cell Biology, vol. 55, p. 110a, 1972.

[66] E. Rieder, C. V. Gay, and H. Schraer, "Autoradiographic localization of carbonic anhydrase in the developing chorioallantoic membrane," Anatomy and Embryology, vol. 159, no. 1, pp. 17-31, 1980.

[67] N. L. Nakhoul and L. L. Hamm, "Vacuolar $\mathrm{H}^{+}$-ATPase in the kidney," Journal of Nephrology, vol. 15, supplement 5, pp. S22-S31, 2002.

[68] M. J. Packard and L. D. Lohmiller, "Mineral status of embryos of domestic fowl following exposure in vivo to the carbonic anhydrase inhibitor acetazolamide," Comparative Biochemistry and Physiology, vol. 132, no. 2, pp. 257-265, 2002.

[69] P. T. Bonar and J. R. Casey, "Plasma membrane $\mathrm{Cl}^{-} / \mathrm{HCO}_{3}{ }^{-}$ exchangers: structure, mechanism and physiology," Channels, vol. 2, no. 5, pp. 337-345, 2008.

[70] G. J. Schwartz, J. Barasch, and Q. Al-Awqati, "Plasticity of functional epithelial polarity," Nature, vol. 318, no. 6044, pp. 368-371, 1985.

[71] S. L. Alper, J. Natale, S. Gluck, H. F. Lodish, and D. Brown, "Subtypes of intercalated cells in rat kidney collecting duct defined by antibodies against erythroid band 3 and renal vacuolar $\mathrm{H}^{+}$-ATPase," Proceedings of the National Academy of Sciences of the United States of America, vol. 86, no. 14, pp. 5429-5433, 1989.

[72] D. Brown and S. Breton, "Mitochondria-rich, protonsecreting epithelial cells," The Journal of Experimental Biology, vol. 199, no. 11, pp. 2345-2358, 1996.

[73] D. Brown, T. G. Paunescu, S. Breton, and V. Marshansky, "Regulation of the V-ATPase in kidney epithelial cells: dual role in acid-base homeostasis and vesicle trafficking," The Journal of Experimental Biology, vol. 212, no. 11, pp. 17621772, 2009.

[74] C. A. Wagner, O. Devuyst, S. Bourgeois, and N. Mohebbi, "Regulated acid-base transport in the collecting duct," Pflugers Archiv European Journal of Physiology, vol. 458, no. 1, pp. 137-156, 2009.

[75] J. W. Vince and R. A. F. Reithmeier, "Carbonic anhydrase II binds to the carboxyl terminus of human band 3, the erythrocyte $\mathrm{Cl}^{-} / \mathrm{HCO}_{3}{ }^{-}$exchanger," Journal of Biological Chemistry, vol. 273, no. 43, pp. 28430-28437, 1998. 
[76] J. W. Vince and R. A. F. Reithmeier, "Identification of the carbonic anhydrase II binding site in the $\mathrm{Cl}^{-} / \mathrm{HCO}_{3}{ }^{-}$anion exchanger AE1," Biochemistry, vol. 39, no. 18, pp. 5527-5533, 2000.

[77] H. L. McMurtrie, H. J. Cleary, B. V. Alvarez, et al., "The bicarbonate transport metabolon," Journal of Enzyme Inhibition and Medicinal Chemistry, vol. 19, no. 3, pp. 231-236, 2004.

[78] F. B. Loiselle, P. E. Morgan, B. V. Alvarez, and J. R. Casey, "Regulation of the human $\mathrm{NBC} 3 \mathrm{Na}^{+} / \mathrm{HCO}_{3}{ }^{-}$cotransporter by carbonic anhydrase II and PKA," American Journal of Physiology, vol. 286, no. 6, pp. C1423-C1433, 2004.

[79] D. Sterling, R. A. F. Reithmeier, and J. R. Casey, "A transport metabolon: functional interaction of carbonic anhydrase II and chloride/bicarbonate exchangers," Journal of Biological Chemistry, vol. 276, no. 51, pp. 47886-47894, 2001.

[80] C. M. Dawes and K. Simkiss, "The acid-base status of the blood of the developing chick embryo," The Journal of Experimental Biology, vol. 50, no. 1, pp. 79-86, 1969.

[81] R. J. Crooks and K. Simkiss, "Respiratory acidosis and eggshell resorption by the chick embryo," The Journal of Experimental Biology, vol. 61, no. 1, pp. 197-202, 1974.

[82] C. M. Dawes and K. Simkiss, "The effects of respiratory acidosis in the chick embryo," The Journal of Experimental Biology, vol. 55, no. 1, pp. 77-84, 1971.

[83] M. F. Romero, P. Fong, U. V. Berger, M. A. Hediger, and W. F. Boron, "Cloning and functional expression of $\mathrm{rNBC}$, an electrogenic $\mathrm{Na}^{+} / \mathrm{HCO}_{3}{ }^{-}$cotransporter from rat kidney," American Journal of Physiology, vol. 274, no. 2, pp. F425F432, 1998.

[84] F. Thévenod, E. Roussa, B. M. Schmitt, and M. F. Romero, "Cloning and immunolocalization of a rat pancreatic $\mathrm{Na}^{+}$ bicarbonate cotransporter," Biochemical and Biophysical Research Communications, vol. 264, no. 1, pp. 291-298, 1999.

[85] E. Roussa, " $\mathrm{H}^{+}$and $\mathrm{HCO}_{3}{ }^{-}$transporters in human salivary ducts. An immunohistochemical study," Histochemical Journal, vol. 33, no. 6, pp. 337-344, 2001.

[86] K. Park, P. T. Hurley, E. Roussa, et al., "Expression of a sodium bicarbonate cotransporter in human parotid salivary glands," Archives of Oral Biology, vol. 47, no. 1, pp. 1-9, 2002.

[87] R. S. Holmes, "Purification, molecular properties and ontogeny of carbonic anhydrase isozymes. Evidence for A, B and $\mathrm{C}$ isozymes in avian and mammalian tissues," European Journal of Biochemistry, vol. 78, no. 2, pp. 511-520, 1977.

[88] M. Schwartz, S. A. Ernst, G. J. Siegel, and B. W. Agranoff, "Immunocytochemical localization of $\left(\mathrm{Na}^{+}, \mathrm{K}^{+}\right)$-ATPase in the goldfish optic nerve," Journal of Neurochemistry, vol. 36, no. 1, pp. 107-115, 1981.

[89] H. Holthofer, B. A. Schulte, and S. S. Spicer, "Heterogeneity of apical glycoconjugates in kidney collecting ducts: further studies using simultaneous detection of lectin binding sites and immunocytochemical detection of key transport enzymes," Histochemical Journal, vol. 20, no. 9, pp. 471-477, 1988.

[90] S. S. Spicer and B. A. Schulte, "Diversity of cell glycoconjugates shown histochemically: a perspective," The Journal of Histochemistry and Cytochemistry, vol. 40, no. 1, pp. 1-38, 1992.

[91] S. Sugii, E. A. Kabat, and H. H. Baer, "Further immunochemical studies on the combining sites of Lotus tetragonolobus and Ulex europaeus I and II lectins," Carbohydrate Research, vol. 99, no. 1, pp. 99-101, 1982.
[92] H. Uedaira and H. Uedaira, "Role of hydration of polyhydroxy compounds in biological systems," Cellular and Molecular Biology, vol. 47, no. 5, pp. 823-829, 2001.

[93] K. Simkiss, "Water and ionic fluxes inside the egg," American Zoology, vol. 20, pp. 385-393, 1980.

[94] M. L. Ponce and H. K. Kleinmann, "The chick chorioallantoic membrane as an in vivo angiogenesis model," Current Protocols in Cell Biology, chapter 19, unit 19.5, 2003.

[95] A. C. Tufan and N. L. Satiroglu-Tufan, "The chick embryo chorioallantoic membrane as a model system for the study of tumor angiogenesis, invasion and development of antiangiogenic agents," Current Cancer Drug Targets, vol. 5, no. 4, pp. 249-266, 2005.

[96] D. Ribatti, "Chick embryo chorioallantoic membrane as a useful tool to study angiogenesis," International Review of Cell and Molecular Biology, vol. 270, pp. 181-224, 2008.

[97] E. I. Deryugina and J. P. Quigley, “Chapter 2. Chick embryo chorioallantoic membrane models to quantify angiogenesis induced by inflammatory and tumor cells or purified effector molecules," Methods in Enzymology, vol. 444, pp. 21-41, 2008.

[98] E. I. Deryugina and J. P. Quigley, "Chick embryo chorioallantoic membrane model systems to study and visualize human tumor cell metastasis," Histochemistry and Cell Biology, vol. 130, no. 6, pp. 1119-1130, 2008.

[99] D. Mangieri, B. Nico, A. M. L. Coluccia, A. Vacca, M. Ponzoni, and D. Ribatti, "An alternative in vivo system for testing angiogenic potential of human neuroblastoma cells," Cancer Letters, vol. 277, no. 2, pp. 199-204, 2009.

[100] C. L. L. Saw, P. W. S. Heng, and C. V. Liew, "Chick chorioallantoic membrane as an in situ biological membrane for pharmaceutical formulation development: a review," Drug Development and Industrial Pharmacy, vol. 34, no. 11, pp. 1168-1177, 2008.

[101] D. Slodownik, I. Grinberg, R. M. Spira, Y. Skornik, and R. S. Goldstein, "The human skin/chick chorioallantoic membrane model accurately predicts the potency of cosmetic allergens," Experimental Dermatology, vol. 18, no. 4, pp. 409413, 2009.

[102] L. C. Albergotti, H. J. Hamlin, M. W. McCoy, and L. J. Guillette Jr., "Endocrine activity of extraembryonic membranes extends beyond placental amniotes," PLoS ONE, vol. 4, no. 5, article e5452, 2009. 

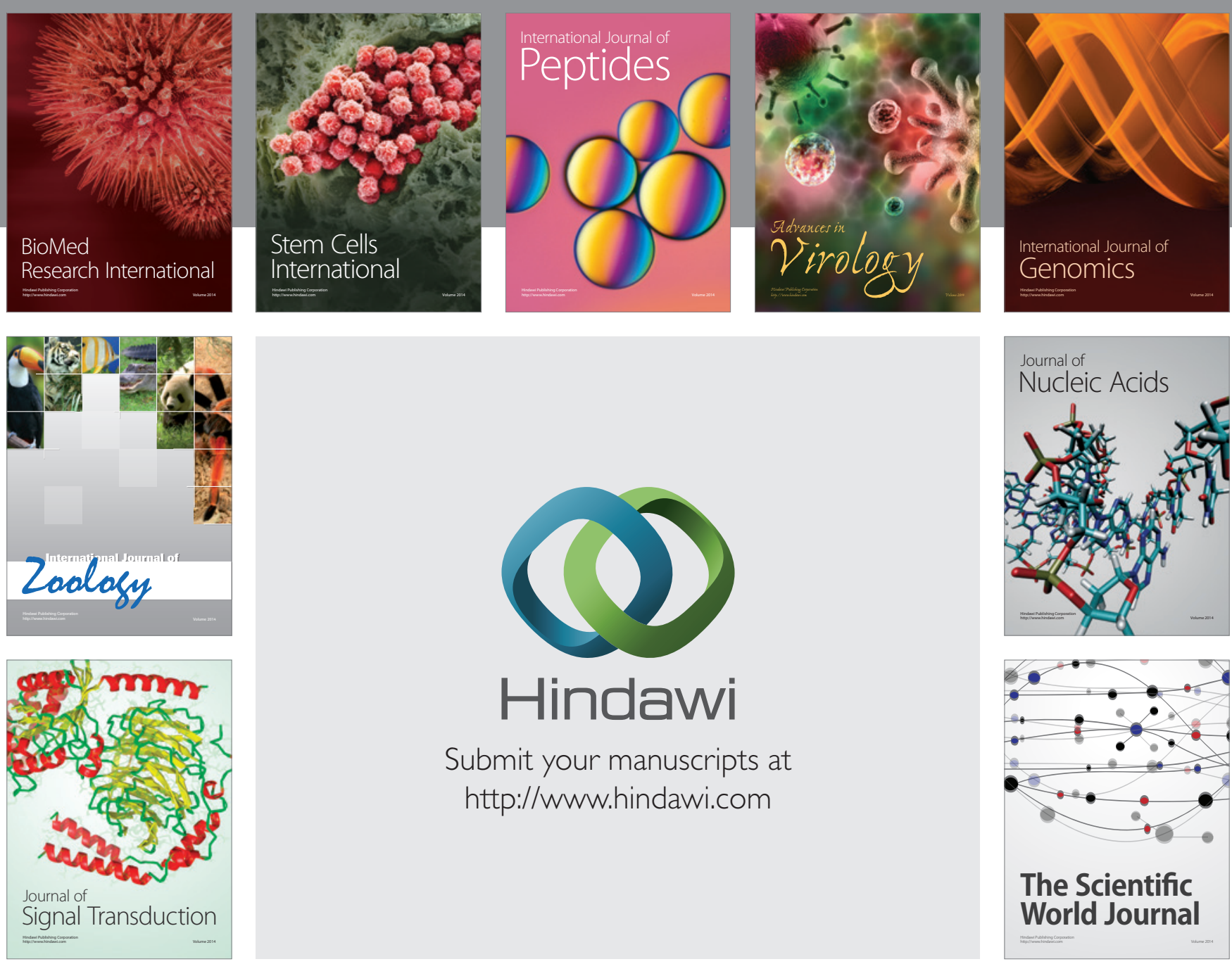

Submit your manuscripts at

http://www.hindawi.com
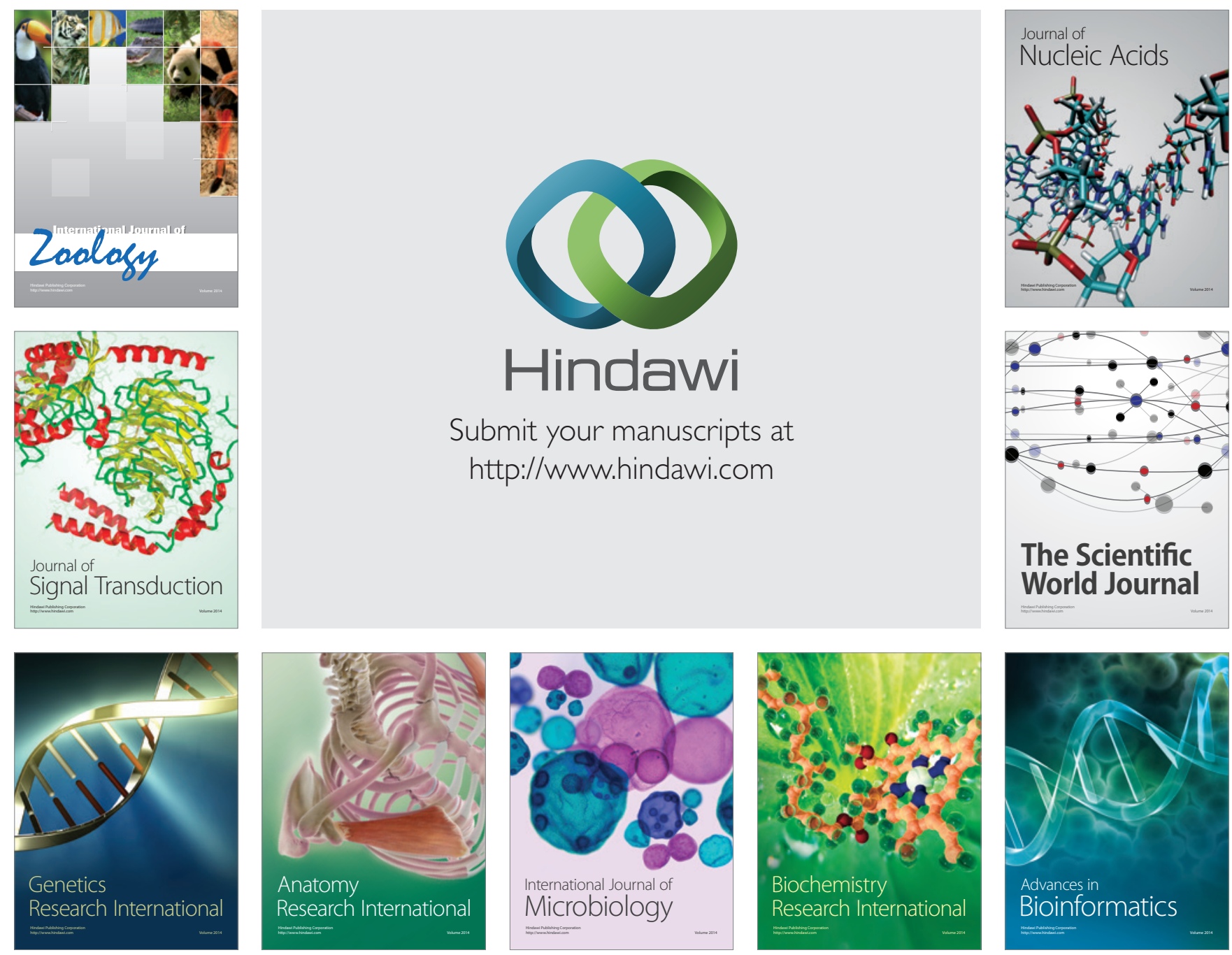

The Scientific World Journal
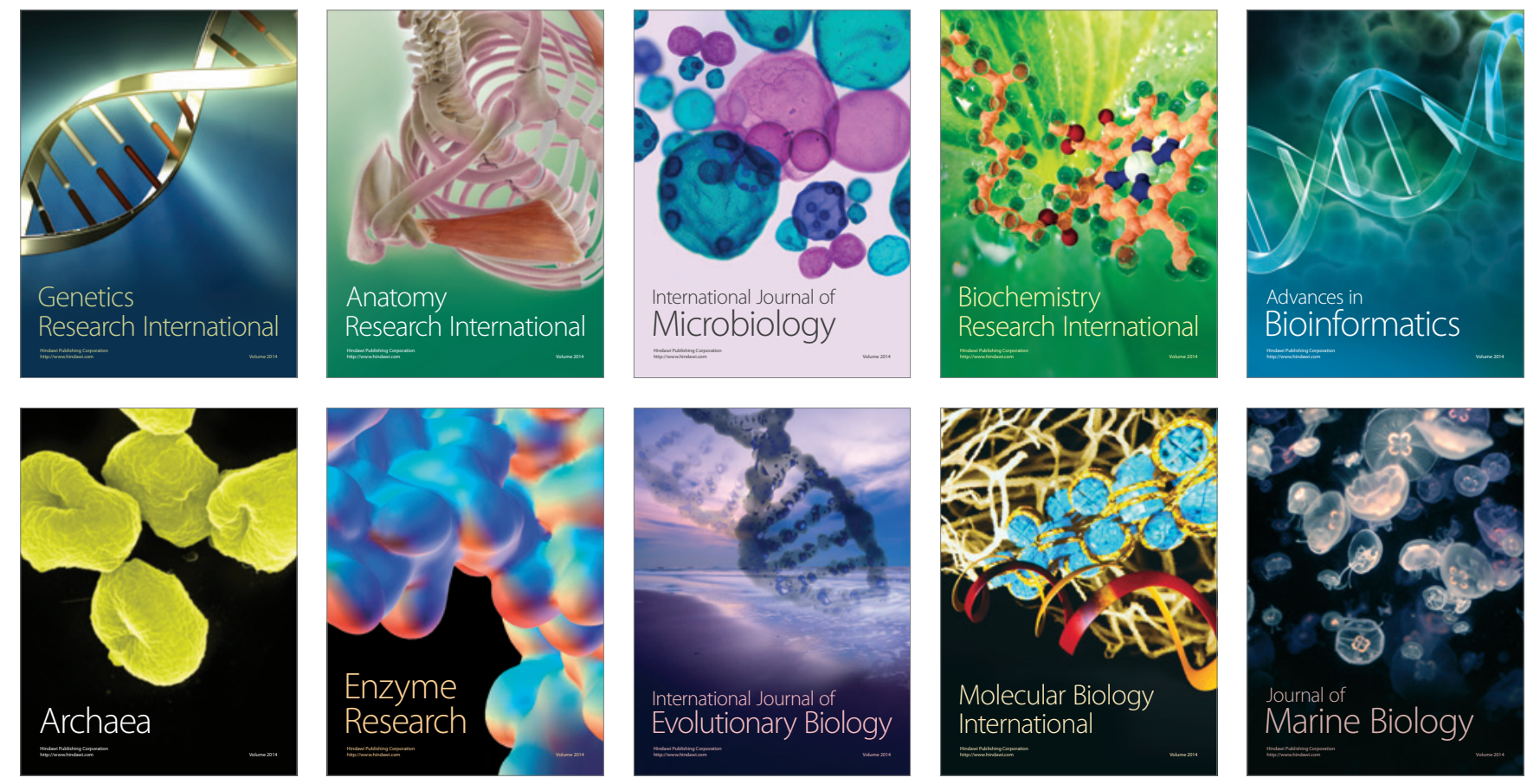